\title{
Lipid, Lipoprotein and APO-A and APO-B Lipoprotein Distribution in Italian and Swiss Schoolchildren. The Geneva Survey
}

\author{
I. OBERHÄNSLI, ${ }^{(44)}$ D. POMETTA, H. MICHELI, L. RAYMOND, AND A. SUENRAM \\ Clinique de Pédiatrie et Service de Santé de la Jeunesse [I.O.J, Division de Diabétologie, Département de Médecine \\ [D.P., H.M., A.S.], and Institut de Médecine Sociale et Préventive, [L.R.] Université de Genève, Geneva, Switzerland
}

\section{Summary}

Cholesterol and triglyceride lipid, lipoprotein as well as apolipoprotein $A$ and $B$ levels, are presented for Italian and Swiss schoolchildren of similar socio-economic origin, living in Geneva, and ranging in age from 8-9 and 14-15 years.

This cross-sectional study revealed some differences associated with the ethnic origin of the participants. Furthermore subtle changes were related to age, associated with puberty and were sex-specific.

Apolipoprotein A and B levels were found to be significantly related to age and less significantly to sex, whereas apolipoprotein A levels decrease with puberty, apolipoprotein $B$ levels increase slightly.

Of the 387 Italian and the 416 Swiss participants, 173 Italian and 193 Swiss children had a complete lipoprotein examination including apolipoprotein determination, whereas serum cholesterol and serum triglycerides were studied in the total group.

There is increasing evidence that atherosclerotic lesions start in childhood $(3,13,25,30,35)$. Consequently, primary prevention has to begin early in life and affect behavior (diet, smoking, physical activity, etc.) $(4,11,22,23,37)$.

Among risk factors associated with coronary heart disease and stroke, LDL cholesterol, VLDL triglyceride, low HDL cholesterol, lipid and lipoprotein concentrations have been shown to correlate closely with the development of atherosclerosis in adults $(5,14$, $18,19,20,28,42$ ).

In children, precursors of cardiovascular risk factors can be identified. In several countries investigations in this field have been recently accomplished $(15,16,17,35,38)$, but results of plasma lipoprotein lipids have been reported $(6,10,21,32,40)$ in limited numbers.

Apolipoproteins have recently been investigated in adults $(1,2)$ whereas normal values in children have to our knowledge not yet been published.

Differences in lipid and lipoprotein levels have been shown among individuals of different countries, different races and/or ethnic groups $(10,14,18,21,24)$; therefore, it was of interest to study the influence of ethnic and environmental factors on serum lipids, lipoproteins and apolipoproteins A and B in schoolchildren of Italian and Swiss origin, living in Geneva, under comparable socio-economic conditions.

\section{MATERIALS AND METHODS}

Schoolchildren of Italian and Swiss nationality, living in $\mathrm{Ge}$ neva, were investigated during the school year 1977-78 at the age of 13 years 9 months up to 15 years 5 months and at the age of 8 years 9 months up to 10 years 5 months. Although most of the older Italian participants were born in Italy, the younger were born mainly in Switzerland. All of them lived for several years (7-12 years) in Geneva and all participants belonged to the blue collar class. They were randomly selected from the official school lists, which indicated the socio-economic and professional status of the head of the family, nationality, birth date and sex.

From the solicited population approximately $1 / 3$ agreed to participate in the study. The reason for refusal was the venous punctures for the blood sampling. No differences were found between participating and nonparticipating children concerning anthropometric measurements, family history and morbidity.

Investigations and laboratory examinations were standardized according to the WHO protocol with detailed documentation of the procedure (41). Informed consent was obtained from the parents of the participants. After a $10-12 \mathrm{~h}$ overnight fast, six to eight children were examined per morning at the school health service center. Height and body weight were measured and a venous blood sample was withdrawn. After breakfast, an extensive medical, family and nutritional history, including detailed drug history and physical examination including blood pressure and anthropometric measurements were performed.

Ninety-eight Italian and 111 Swiss boys, 98 Italian and 103 Swiss girls aged 8-9 years; 96 Italian and 102 Swiss boys, 95 Italian and 100 Swiss girls aged 14-15 years were studied.

Lipid and lipoprotein measurements. Cholesterol was measured enzymatically after hydrolysis with ethanolic $\mathrm{KOH}$ and nonane extraction (33). Triglycerides were determined according to Soloni (36).

Lipoproteins were separated after preparative ultracentrifugation as previously described (27).

The cholesterol and triglyceride measuring methods had previously been standardized by four European laboratories (24); they were rechecked during the study.

Serum apolipoproteins $\mathrm{A}$ and $\mathrm{B}$ were determined by electroimmunoassay according to Curry et al. $(7,8)$ using a commercially available "anti-alpha-lipoprotein" serum (Boehringer No. 2792 and No. 3301) and a monospecific "anti-beta-lipoprotein" serum. Specificity and purity of the antisera was checked by immunoelectrophoresis. With each run, at least two dilutions of a reference plasma were included; these reference sera had been standardized against pure HDL and LDL preparations.

For HDL the total protein content was referred to as Apo-A (90-95\% of HDL apolipoprotein) whereas the Apo-B concentration is given in arbitrary units.

Although total plasma cholesterol and total plasma triglyceride determination was carried out in all children, HDL, LDL, VLDL and Apo-A and Apo-B lipoproteins were measured in a randomly selected subgroup of participants: 46 Italian and 48 Swiss boys; 46 Italian and 47 Swiss girls aged 8-9 years, as well as in 38 Italian and 47 Swiss boys and 43 Italian and 51 Swiss girls aged 14-15 years.

Heights and weights were measured in a standardized fashion (41): the height in the standing position, without shoes, in centi- 
meters to the nearest $0.1 \mathrm{~cm}$, the back against a board, eyes looking straight ahead with a set square resting on the scalp and against the board. The weight was measured in kilograms to the nearest $0.1 \mathrm{~kg}$, the subjects wearing only light underwear and no shoes. The scales were calibrated to zero before the beginning of each days screening. The ponderal index used was the Quetelet index: $\frac{\text { weight in } \mathrm{kg}}{(\text { height in } \mathrm{cm})^{2}} \times 1000$

The statistical package for the socal sciences was used for the statistical analysis.

To assess differences between Italian and Swiss children a covariance analysis was performed.

Serum triglyceride, VLDL triglycerides and VLDL cholesterol values were expressed in natural logarithmic transformation.

\section{RESULTS}

The mean values for total serum cholesterol and lipoprotein cholesterol (HDL, LDL, VLDL) as well as for total serum triglycerides and lipoprotein triglycerides (HDL, LDL, VLDL) were compared between Italian and Swiss participants of the same sex and age.

Total serum cholesterol and total serum triglyceride measurements tend to be higher in Swiss schoolchildren; however, statistical significance is reached only for the triglycerides of the 14-15year-old group and the 8-9-year-old girls (Fig. 1-4). High serum triglyceride levels reflect an increase of both VLDL and LDL triglyceride in boys and in girls.

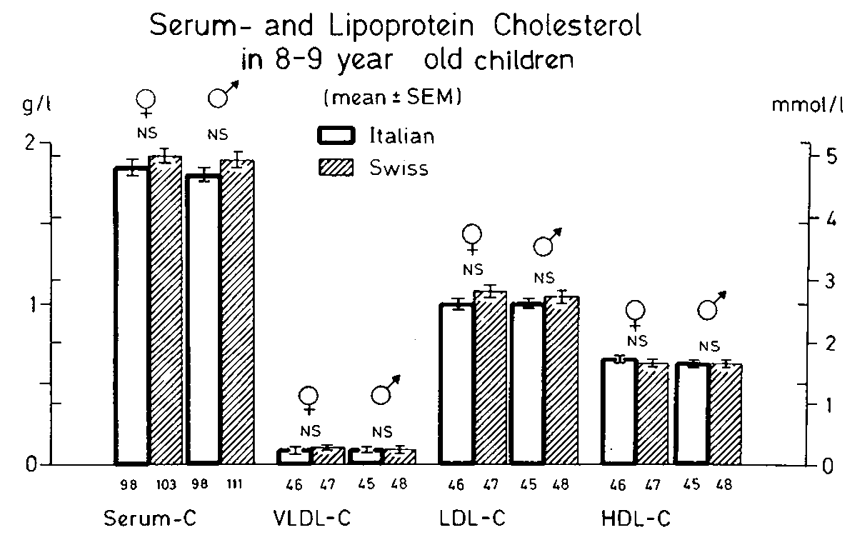

Fig. 1

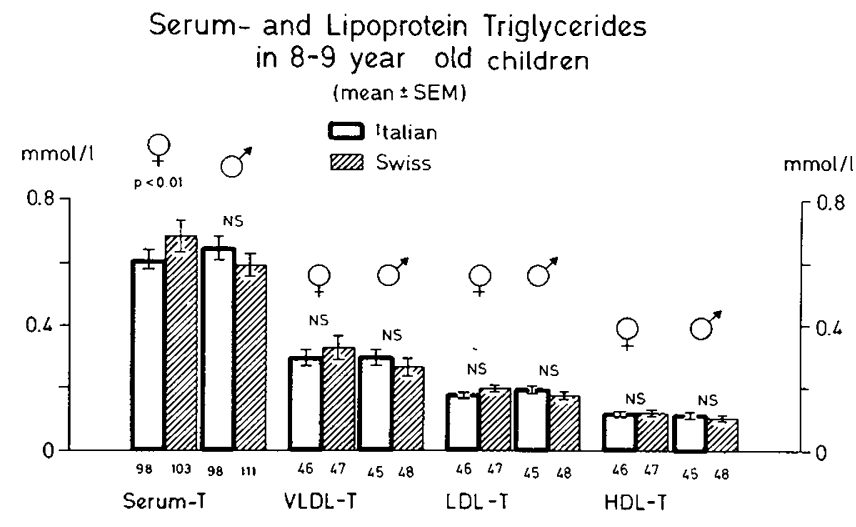

Fig. 2
Table 1 shows the measurements of central tendency (mean \pm S.D.) and selected positional values (percentiles) for serum and lipoproteins cholesterol and triglyceride lipoproteins, presented for the combined Italian and Swiss boys and girls of the two age groups.

There are only slight variations between the mean and the 50th percentile values.

Comparative results of Apo-A and Apo-B lipoproteins are shown in Table 2 together with the Quetelet ponderal index, total serum cholesterol and triglycerides as well as HDL cholesterol values for children in whom the complete study of all lipoprotein fractions was performed. Some minor differences in apolipoproteins between Swiss and Italian children were statistically not significant.

Age-related differences were observed in both ethnic groups: serum cholesterol and lipoprotein cholesterol levels are higher in the 8-9-year-old children than in the 14-15-year-old. Serum triglyceride and lipoprotein triglycerides are lower in the younger age group than in 14-15-year-old girls and boys and increased with age.

Sex differences are observed in Italian and Swiss children of both age groups. The girls show higher serum lipoprotein cholesterol and triglyceride levels.

Apolipoprotein A values were markedly lower in the 14-15year-old children of both ethnic origins than in the 8-9-year-old, whereas apolipoprotein B levels showed a tendency to be lower in the younger children. Apolipoproteins A and B have no significant sex specific differences in the Geneva study group.

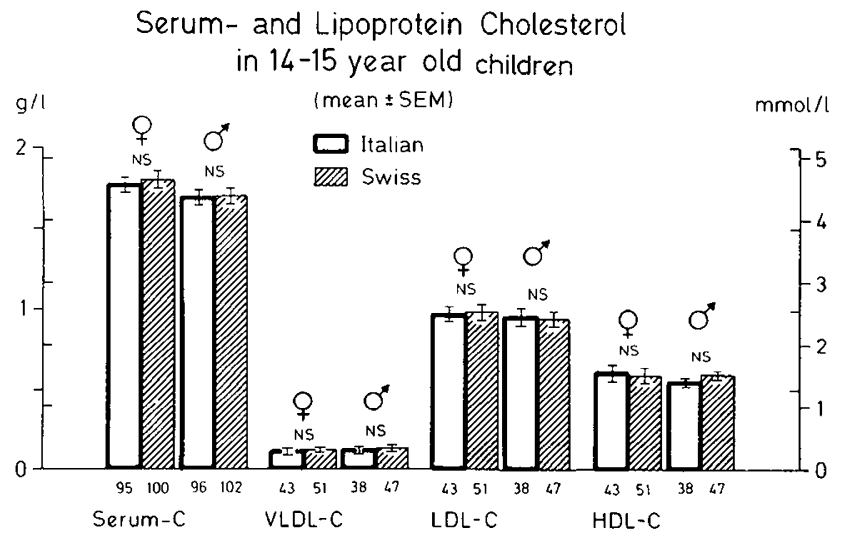

Fig. 3

Serum- and Lipoprotein Triglycerides in $14-15$ year old children (mean \pm SEM)

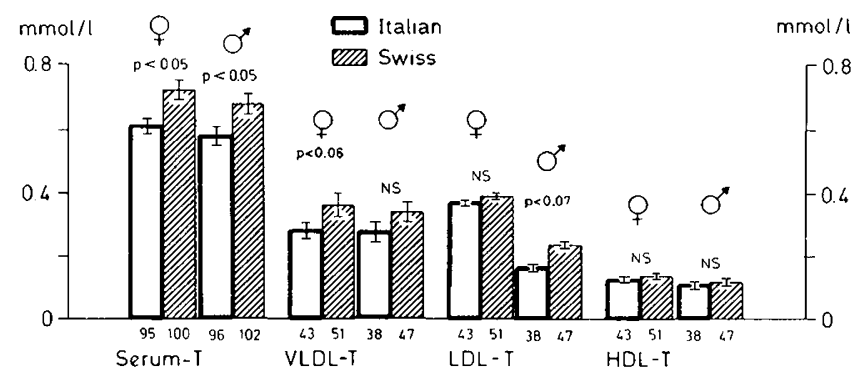

Fig. 4

Fig. 1-4. Serum and lipoprotein cholesterol and serum and lipoprotein triglyceride values in Italian and Swiss schoolchildren are shown, separated according to sex, ethnic group and age. The colums indicate the mean values \pm 1 S.E. of the mean (SE). The numbers show the analyses in participants done for each group. Serum C, serum cholesterol; VLDL-C, very low density lipoprotein cholesterol; LDL-C, low density lipoprotein cholesterol; HDLC, high density lipoprotein cholesterol; Serum-T, serum triglycerides; VLDL-T, very low density lipoprotein triglycerides; LDL-T, low density lipoprotein triglycerides; HDL-T, high density lipoprotein triglycerides; and NS, nonsignificant. 
Table 1. Plasma lipids and lipoproteins in pooled italian and swiss schoolchildren

\begin{tabular}{|c|c|c|c|c|c|c|c|c|c|c|c|c|c|c|c|c|c|}
\hline & \multirow[b]{2}{*}{ Age } & \multicolumn{8}{|c|}{ Boys } & \multicolumn{8}{|c|}{ Girls } \\
\hline & & $\mathrm{Nbr}$ & Mean & S.D. & 10 th & 25 th & 50 th & 75th & 90th & $\mathrm{Nbr}$ & Mean & S.D. & 10th & 25 th & 50th & 75th & 90th \\
\hline \multirow{2}{*}{$\begin{array}{l}\text { Total serum' cholesterol } \\
\text { (mmole/liter) }\end{array}$} & $8-9$ & 209 & 4.69 & 0.75 & 3.70 & 4.08 & 4.75 & 5.13 & 5.66 & 201 & 4.92 & 0.81 & 3.87 & 4.38 & 4.87 & 5.47 & 5.97 \\
\hline & $14-15$ & 198 & 4.34 & 0.71 & 3.51 & 3.80 & 4.34 & 4.78 & 5.17 & 195 & 4.46 & 0.81 & 3.46 & 3.82 & 4.37 & 5.00 & 5.48 \\
\hline \multirow{2}{*}{$\begin{array}{l}\text { HDL-cholesterol } \\
\text { (mmole/liter) }\end{array}$} & $8-9$ & 93 & 1.62 & 0.27 & 1.26 & 1.42 & 1.58 & 1.79 & 2.02 & 93 & 1.63 & 0.32 & 1.31 & 1.38 & 1.58 & 1.78 & 2.00 \\
\hline & $14-15$ & 85 & 1.49 & 0.30 & 1.14 & 1.24 & 1.44 & 1.63 & 1.78 & 94 & 1.53 & 0.29 & 1.16 & 1.33 & 1.48 & 1.70 & 1.93 \\
\hline \multirow{2}{*}{$\begin{array}{l}\text { LDL-cholesterol } \\
\text { (mmole/liter) }\end{array}$} & $8-9$ & 93 & 2.64 & 0.58 & 1.79 & 2.30 & 2.62 & 3.01 & 3.33 & 93 & 2.72 & 0.62 & 1.86 & 2.30 & 2.75 & 3.11 & 3.39 \\
\hline & $14-15$ & 85 & 2.47 & 0.51 & 1.82 & 2.04 & 2.45 & 2.76 & 3.23 & 94 & 2.53 & 0.60 & 1.81 & 2.05 & 2.48 & 2.90 & 3.41 \\
\hline \multirow{2}{*}{$\begin{array}{l}\text { VLDL-cholesterol } \\
\text { (mmole/liter) }\end{array}$} & $8-9$ & 93 & 0.21 & 0.12 & 0.07 & 0.11 & 0.17 & 0.24 & 0.34 & 93 & 0.2 & 0.15 & 0.05 & 0.11 & 0.18 & 0.28 & 0.44 \\
\hline & $14-15$ & 85 & 0.31 & 0.13 & 0.14 & 0.19 & 0.28 & 0.37 & 0.49 & 94 & 0.34 & 0.16 & 0.14 & 0.19 & 0.32 & 0.42 & 0.55 \\
\hline \multirow{2}{*}{$\begin{array}{l}\text { Total serum triglycerides } \\
\text { (mmole/liter) }\end{array}$} & $8-9$ & 209 & 0.63 & 0.27 & 0.33 & 0.45 & 0.56 & 0.74 & 1.01 & 201 & 0.65 & 0.35 & 0.35 & 0.44 & 0.56 & 0.77 & 0.98 \\
\hline & $14-15$ & 198 & 0.67 & 0.37 & 0.37 & 0.48 & 0.62 & 0.81 & 1.01 & 195 & 0.74 & 0.30 & 0.41 & 0.50 & 0.67 & 0.91 & 1.11 \\
\hline \multirow{2}{*}{$\begin{array}{l}\text { HDL-triglycerides } \\
\text { (mmole/liter) }\end{array}$} & $8-9$ & 94 & 0.1 & 0.0 & 0.07 & 0.08 & 0.11 & 0.13 & 0.1 & 93 & 0 . & 0.0 & 0.07 & 0.08 & 0.12 & 0.14 & 0.17 \\
\hline & $14-15$ & 85 & 0.12 & 0.05 & 0.06 & 0.08 & 0.10 & 0.14 & 0.18 & 94 & 0.13 & 0.06 & 0.06 & 0.08 & 0.12 & 0.16 & 0.19 \\
\hline \multirow{2}{*}{$\begin{array}{l}\text { LDL-triglycerides } \\
\text { (mmole/liter) }\end{array}$} & $8-9$ & 94 & 0.16 & 0.05 & 0.12 & 0.15 & 0.18 & 0.20 & 0.24 & 93 & 0.19 & 0.05 & 0.13 & 0.15 & 0.17 & 0.21 & 0.24 \\
\hline & $14-15$ & 85 & 0.18 & 0.06 & 0.11 & 0.13 & 0.16 & 0.19 & 0.25 & 94 & 0.18 & 0.06 & 0.11 & 0.13 & 0.17 & 0.21 & 0.25 \\
\hline \multirow{2}{*}{$\begin{array}{l}\text { VLDL-triglycerides } \\
\text { (mmole/liter) }\end{array}$} & $8-9$ & 94 & 0.28 & 0.17 & 0.08 & 0.16 & 0.23 & 0.36 & 0.55 & 93 & 0.32 & 0.22 & 0.11 & 0.15 & 0.25 & 0.38 & 0.62 \\
\hline & $14-15$ & 85 & 0.37 & 0.21 & 0.11 & 0.21 & 0.31 & 0.46 & 0.66 & 94 & 0.39 & 0.24 & 0.15 & 0.20 & 0.35 & 0.49 & 0.68 \\
\hline
\end{tabular}

' Converting factor for serum cholesterol mmole/liter $\times 0.387=\mathrm{g} / \mathrm{liter}$.

${ }^{2}$ Converting factor for serum triglycerides mmole/liter $\times 0.875=\mathrm{g} /$ liter.

Table 2. Values of serum cholesterol, serum triglycerides, HDL-cholesterol and APO-lipoprotein A and B in children (Mean \pm S.D.)

\begin{tabular}{|c|c|c|c|c|c|c|c|c|}
\hline & \multicolumn{8}{|c|}{ Schoolchildren } \\
\hline & \multicolumn{4}{|c|}{$8-9$ years old } & \multicolumn{4}{|c|}{$14-15$ years old } \\
\hline & \multicolumn{2}{|c|}{ Girls } & \multicolumn{2}{|c|}{ Boys } & \multicolumn{2}{|c|}{ Girls } & \multicolumn{2}{|c|}{ Boys } \\
\hline & Italian & Swiss & Italian & Swiss & Italian & Swiss & Italian & Swiss \\
\hline Numbers & 46 & 47 & 46 & 48 & 43 & 51 & 38 & 47 \\
\hline \multirow{2}{*}{$\begin{array}{l}\text { Total serum cholesterol } \\
\text { (mmole/liter) }\end{array}$} & 4.78 & 4.97 & 4.61 & 4.83 & 4.57 & 4.67 & 4.40 & 4.39 \\
\hline & \pm 0.76 & \pm 0.75 & \pm 0.73 & \pm 0.62 & \pm 0.66 & \pm 0.78 & \pm 0.68 & \pm 0.60 \\
\hline \multirow{2}{*}{$\begin{array}{l}\text { HDL-cholesterol } \\
\text { (mmole/liter) }\end{array}$} & 1.65 & 1.62 & 1.61 & 1.64 & 1.55 & 1.52 & 1.45 & 1.52 \\
\hline & \pm 0.31 & \pm 0.33 & \pm 0.29 & \pm 0.25 & \pm 0.28 & \pm 0.29 & \pm 0.21 & \pm 0.36 \\
\hline \multirow{2}{*}{$\begin{array}{l}\text { Total serum triglycerides } \\
\text { (mmole/liter) }\end{array}$} & -0.548 & -0.475 & -0.516 & -0.587 & -0.491 & -0.321 & -0.548 & -0.386 \\
\hline & \pm 0.342 & \pm 0.427 & \pm 0.386 & \pm 0.380 & $\pm 0.325^{1}$ & $\pm 0.447^{1}$ & $\pm 0.408^{1}$ & $\pm 0.341^{1}$ \\
\hline Antilog & 0.578 & 0.622 & 0.597 & 0.551 & 0.612 & 0.726 & 0.579 & 0.680 \\
\hline \multirow{2}{*}{$\begin{array}{l}\text { Apo A Lipoprotein } \\
\text { (Arbitary units) }\end{array}$} & 102.44 & 100.68 & 103.72 & 103.22 & 84.91 & 84.29 & 80.68 & 82.71 \\
\hline & \pm 11.14 & \pm 11.01 & \pm 9.19 & \pm 4.76 & \pm 11.85 & \pm 10.24 & \pm 11.00 & \pm 11.28 \\
\hline \multirow{2}{*}{$\begin{array}{l}\text { Apo B Lipoprotein } \\
\text { (Arbitary units) }\end{array}$} & 110.12 & 117.52 & 108.96 & 110.39 & 114.79 & 115.71 & 114.73 & 114.04 \\
\hline & \pm 11.97 & \pm 14.76 & \pm 13.84 & \pm 16.18 & \pm 13.22 & \pm 18.18 & \pm 15.06 & \pm 13.56 \\
\hline \multirow[t]{2}{*}{ Ponderal index (Quetelet) } & $1.72^{1}$ & $1.66^{1}$ & $1.73^{1}$ & $1.64^{1}$ & 2.06 & 2.02 & 2.01 & 1.96 \\
\hline & \pm 0.26 & \pm 0.23 & \pm 0.20 & \pm 0.20 & \pm 0.30 & \pm 0.28 & \pm 0.33 & \pm 0.27 \\
\hline
\end{tabular}

${ }^{1} P<0.05$

In the adolescent group, $18 \%$ of the Italian and $8 \%$ of the Swiss boys drank alcohol at least once a week; $5 \%$ of both ethnic groups smoke cigarettes daily. In the girls of both ethnic groups, 9\% smoked cigarettes but none indicated that they drank alcohol. Among the 8-9-year-old participants none drank alcohol or smoked cigarettes. Except one Swiss girl taking the pill, none of the children took drugs affecting serum lipoproteins.

\section{DISCUSSION}

The importance of lipids and lipoproteins as a risk factor of coronary heart disease and stroke has drawn increasing attention towards research in the pediatric age group. More recently, the studies were not only focused on total serum cholesterol and triglycerides $(23,29,32,35,40)$, but also on lipoprotein levels $(6$, 
$10,21,34,38,42)$. During the last $2-3$ years, apolipoproteins were found to allow even a better discrimination for atherosclerosis in adults $(1,2)$. So far, larger series of apolipoproteins in the pediatric age group have not been published.

Previous studies have shown considerable differences in lipid and lipoprotein levels among countries and ethnic groups $(14,15$, $24,35,38$ ).

In the Geneva schoolchildren of Italian and Swiss nationality with comparable socio-economic conditions, differences in serum triglycerides were observed (Fig. 2 and 4).

The Swiss study groups show higher serum triglycerides. This is not related to increased body weight as the Quetelet ponderal index is lower in the Swiss children than in the Italian. This is in contrast with observations in adults where high serum triglycerides are often related to excessive body weight (20).

As stated, the difference was not related to socio-economical conditions, but could be secondary to nutritional habits. Indeed the nutritional survey in the 14-15-year-old participants shows that Swiss children eat more carbohydrate than the Italian (to be published). Carbohydrates are known to induce hypertriglyceridemia (9). Increased caloric intake has also been shown to induce hypertriglyceridemia; however, the observed difference was not related to differences in total caloric intake.

When serum and lipoprotein cholesterol levels were considered, no differences were found between the two ethnic groups.

The results obtained in the Geneva survey are comparable with results published in the US $(15,29,38)$, in other European countries $(12,21,40)$ and in some developing countries (26). It is, however, noteworthy that mean levels of lipids and lipoproteins of the Geneva study are significantly higher than those reported in the United States by the Mayo Clinic (10) and by the Lipid Research Clinic program prevalence study $(\mathrm{P}<0.01)(39,38)$. Differences in laboratory techniques, and/or economics and nutritional habits could be the origin of this discrepancy. A very important difference was also observed between the Geneva survey and a recently published study in southern Italy (12). This difference was, however, also noticed in the "inter"- Italian studies and can be well explained by the striking socio-economic differences between southern and northern Italy and even more between southern Italy and Geneva. All these observations stress therefore the importance to establish base line values in each country and even in different areas of one and the same country.

Age-related differences were observed. Serum and lipoprotein cholesterol levels were higher in younger children than in the older group, whereas serum triglycerides were significantly higher in the adolescent groups. Surprisingly in the Geneva study, these differences are more marked in girls of both ethnic origins than in boys. The decrease in serum cholesterol is mainly due to decrease in HDL cholesterol and to a much lesser degree in LDL cholesterol. The increase in serum triglycerides is based on an increase in VLDL and LDL triglycerides. It should be mentioned that the children participating in this study were in excellent health, none of them presented familial or secondary hyperlipoproteinemia.

Sex specific differences in serum and lipoprotein cholesterol were observed in the adolescents. Girls tented to have higher serum cholesterol and HDL lipoproteins than boys; however, the differences became significant only when the values of Italian and Swiss girls and boys were combined $(P<0.02)$.

Oral contraceptives are known to affect lipoprotein lipids, but only one girl reported using the pill. Therefore changes cannot be attributed to hormonal treatment. Similarly alcohol consumption and cigarette smoking were not different in the two ethnic groups and could not account for the observed differences.

Recent studies suggest that apolipoproteins could be better discriminators of dyslipoproteinemia than lipids $(2,8)$. Little is known on apolipoprotein distributions in children, and only in small groups. Our data show that apolipoprotein B levels tend to increase with age both in boys and girls, whereas apolipoprotein A values decrease significantly in the older children. These changes are shown more clearly when the ratio of Apo-A/Apo-B is compared between younger and older children. The decrease in
Apo-A could explain the lower HDL cholesterol levels observed in adolescents. No specific sex differences were found for both apolipoprotein A and B concentrations. No ethnic difference has been observed either.

We recently have reported that children of parents, who had a proven myocardial infarction, show lower HDL and higher LDL cholesterol values (31). Apolipoproteins were so far not determinated in these children; they might, however, provide even better discrimination factors and the possibility of early detection of the population at risk.

In conclusion, the Geneva survey compares well with other cross-sectional studies; lipid and lipoprotein values are, however, considerably higher than in the recently published Lipid Research Clinic (31) program prevalence study and certainly higher than in the southern Italian study. This might indicate a generally higher socio-economic standard of Geneva even in the blue collar group.

The observed changes in plasma lipids and lipoproteins in only two age groups indicate some trends, but they demonstrate the importance of lipoprotein measurements not only in localized pediatric populations but also in a standardized national and international longitudinal survey with a special accent on apolipoproteins.

Differences in lipids and lipoproteins of various ethnic groups seem to become less important when these ethnic groups live under comparable socio-economic conditions in the same environment. Our results therefore indicate the importance of environment and socio-economic situation for cardiovascular risk factors.

\section{REFERENCES AND NOTES}

1. Avogaro, P., Bittolo, G. P., Bon, G. B., Gazzolato, G., Belussi, F., and Quinci, G.: Plasma levels of some Apolipoproteins in human atherosclerosis. In: Gatto A. M. Jr., Simth L. C., Allen B. Ed Atherosclerosis V. p. 816-819 (Springer Verlag, New-York, Heidelberg, Berlin 1980).

2. Avogaro, P., Bittolo, Bon, G. B., Gazzolato, G., Quinci, G., and Belussi, F.: Are Apolipoproteins better discriminators than lipids for atherosclerosis? Lancet, 1: 901 (1979).

3. Berenson, G. S., McMahan, C. A., Voors, A. W., Webber, L. S., Srinivasan, S R., Frank, G. C., Foster, Th. A., and Blonde, C. V.: In Berenson G. S. Ed. Cardiovascular risk factors in children. pp. 3-19 (Oxford University Press 1980).

4. Berenson, G. S., McMahan, C. A., Voors, A. W., Webber, L. S., Srinivasan, S R., Frank, G. C., Foster, Th. A., and Blonde, C. V.: Cardiovascular risk factors in children. pp. 289-307, 381-296, 397-413. (Oxford University Press, 1980).

5. Castelli, W. P., Doyle, I. T., Gordon, T., Hames, C. G., Hulley, S. B., Kagan, A., and Zukel, W. J.: HDL-cholesterol and other lipids in coronary heart disease: the cooperative lipoprotein phenotyping study. Circulation, 55: 767 (1977).

6. Christensen, B., Glueck, C. J., Kwiterovich, P., DeGroot, J., Chase, G., Heiss, G., Mowery, R., Tamir, J., and Rifkind B.: Plasma cholesterol and triglyceride distribution in 13665 children and adolescents. The lipid research clinics program prevalence study. Pediatr. Res. 14: 194 (1980)

7. Curry, M. D., Alanpovic, P., and Suenram. A.: Determination of Apolipoprotein A and its constitutive A I and A II polypeptides by separate electroimmunoassays. Clin. Chem., 22: 315 (1976).

8. Curry, M. D., Gustafson, A., Alanpovic, P., and McConathy, W. J.: Electroimmunoassays, radio-immunoassay and radial immunodiffusion assay evaluated for quantification of human Apolipoprotein B. Clin. Chem., 24: 280 (1978).

9. Den Besten, L., Reyna, R. H., and Connor, W. E.: The different effects on the serum lipids and fecal steroids of high carbohydrate diets given orally or intravenously. J. of Clin. Invest., 52: 1384 (1973)

10. Ellefson, R. D., Elvebach, L. R. Hadgson, P. A., and Weidmann W. H. Cholesterol and triglycerides in serum lipoproteins of young persons in Rochester, Minnesota. Mayo Clinic Proc., 53: 307 (1978).

11. Epstein, F. H., Gützwiller, F., Howald, H., Junod, B., and Schweizer W.: Prävention der Atherosclerose: Grundlage heute. Schweiz. Med. Wschr., 109: 1171 (1979).

12. Farinaro, E., Panico, S., and Mancini, M.: The know your body program in Italy. Preventive Med., 10: 187 (1981).

13. Fomon, S. J.: Prevention of atheroscierosis: Nutritional considerations. In: Strong W. P. Ed.: Atherosclerosis: Its pediatric aspects. pp. 231-250 (Grune \& Stratton, New-York, San Francisco, London, 1978).

14. Forde, O. H., Thelle, D. S., Miller, N. E., and Mjøs, D. D.: The Throms $\varnothing$ heart study: Distribution of serum cholesterol between high density and low density lipoproteins in subjects of Norse, Finnish and Lappish ethnic origin. Acta Med. Scand., 203: 21 (1978).

15. Frerichs, R. R., Srinivasan, S. R., Webber, L. S., and Berenson, G. S.: Serum cholesterol and triglycerides levels in 3446 children from a biracial community: The Bogalusa heart study. Circulation 54: 302 (1976).

16. Glueck, C. J. and Kelley, K.: Hypercholesterolemia and hyperalphalipoproteinemia in school children. Pediatrics, 62: 478 (1978).

17. Godfrey, R. C., Stenhouse, N. S., Cullen, K. H., and Blackmann V.: Cholesterol and the child: study of cholesterol levels of Busselton schoolchildren and 
parents. Aüst. J. Pediatr. 8: 72 (1972).

18. Heiss, G., Tamir, I., Davis, C. E., Tyroler, H. A., Rifkind, B. M., Schonfeld, G. Jacobs, D., and Frantz I. D.: Lipoprotein cholesterol distributions in selected North-American populations. The lipid research clinics program prevalence study. Circulation, 61: 302 (1980)

19. Kannel, W. B., Castelli, W. P., Gordon, T., and McNamara, P. M.: Serum cholesterol lipoproteins and risk of coronary heart disease. The Framingham study. Am. Inst. Med., 74: 1 (1974).

20. Keys, A.: Coronary heart disease-the global picture. Atherosclerosis, 22: 149 (1975).

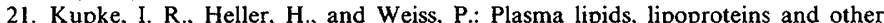
factors related to atherosclerosis: A pediatric study in Düsseldorf. Proceedings of the 8 World Congress of Cardiology, Tokyo, 17-23 Sept. 1978. pp. 391-392, Ed. S. Hayase and S. Murao, 13/Atherosclerosis and hypertension--pediatric aspects (1980).

22. Lauer, R. M. and Shekelle, R. B.: Childhood prevention of atherosclerosis and hypertension, pp: 37-41, 375-405, (Raven Press, New-York, 1978).

23. Lauer, R. M., Connor, W. E., Leaverton, P. E., Reiter, M. A., and Clarke, W. R. Coronary risk factors in school children: The Muscatine study. J. Pediatr., 86: 697 (1975).

24. Lewis, B., Chait, A., Sirgurdson, G., Mancini, M., Farinaro, E., Oriente, P. Carlson, L. A., Ericsson, M., Micheli, H., and Pometta, D.: Serum lipoproteins in four european communities-a quantitative comparison. Europ. J. Clin. Invest., 8: 165 (1978).

25. McGill, H. C.: Morphologic development of the atherosclerotic plaque. In: Lauer, R. M. and Shekelle, R. B. Ed., Childhood prevention of atherosclerosis and hypertension. pp. 41-49 (Raven Press, New York, I980).

26. Mendoza, S., Contreras, G., Ineichen, E., Ferandez, M., Nucete, H., Morrison, J. A., Gartside, P. S., and Glueck, J.: Lipids and lipoproteins in Venezuelan and American schoolchildren within and cross cultural comparison. Pediatr. Res., 14: 272 (1980)

27. Micheli, H., Pometta, D.. Jornot, C., and Scherrer, J. R.: High density lipoprotein cholesterol in male relatives of coronary patients. Atherosclerosis, 32: 269 (1979).

28. Miller, G. J. and Miller, W. E.: Plasma high density lipoprotein concentration and development of ischaemic heart disease. Lancet, 1: 16 (1975)

29. Morrison, J. A., DeGroot, I., Edwards, B. K., Kelly, K. A., and Glueck, C. J.: Plasma cholesterol and triglyceride levels in 6775 schoolchildren ages 6-17. Metabolism, 26: 1199 (1977)

30. Newman, W. P. and Strong, J. P.: Natural history, geographic, pathology and pediatric aspects of atherosclerosis. In: Strong. W. P. Ed.: Atherosclerosis: Its pediatric aspects. pp 15-40, (Grune \& Stratton, New-York, San Francisco, London, 1978.)

31. Oberhänsli, I., Pometta, D., Micheli, H., and Raymond, L.: Lipoproteines de haute densité chez les enfants de malades coronariens. Helv. Paediatr. Acta 36:
135 (1981).

32. Okuni, M., Hayashi, K., Kiryu, S., and Yamanchi, K.: Risk factors for atherosclerosis in Japanese children. In: Hayase S. and Murao S. Ed. Proceedings of the 8th World Congress of Cardiology, Tokyo, 17-23 Sept. 1978. pp. 141-418 (13/atherosclerosis and hypertension-pediatric aspects, 1980).

33. Roschlan, P., Bernt, E., and Gruber, W.: Enzymatische Bestimmung des GesamtCholesterin in Serum. Z. Klin. Chem. Klin. Biochem., 12: 403 (1974).

34. Ross, R.: Endothelial integrity, cell proliferation and atherosclerosis. In: Lauer R. M., Schekelle, R. B. Ed. Childhood prevention of atherosclerosis and hypertension, pp 51-60 (Raven Press, New-York, 1980)

35. Savage, J. P., Hamman, R. F., and Bartha, G.: Serum cholesterol in American (PIMA) Indian children and adolescents. Pediatrics, 58: 274 (1976).

36. Soloni, F. G.: Simplified manual micromethod for determination of serum triglycerides. Clin. Chem., 17: 529 (1971).

37. Strong, W. B.: Is atherosclerosis a pediatric problem? In: Strong, W. B. Ed. Atherosclerosis: Its pediatric aspects pp 1-15 (Grune \& Stratton, New-York, San Francisco, London, 1978).

38. Tamir, I., Heiss, G., Glueck, C. J., Christensen, B., Kwiterovich, P., and Rifkind, B. M.: Lipid and lipoprotein distributions in white children ages 6-19 years. The lipid research clinics program prevalence study. J. Chron. Dis., 34: 27 (1981).

39. Tyroler, H. A.: Epidemiology of plasma high-density lipoprotein cholesterol levels. The lipid research clinics program prevalence study pp 1-136, AHA Monography No 73. Circulation 62 (suppl IV) (1980).

40. Van der Haar, F. and Kromhout, D.: Food intake, nutritional, anthropometry and blood chemical parameters in 3 selected Dutch schoolchildren populations. Ed. Veenmann H. and Zonen D. Y. Wageningen, Holland (1978).

41. Collaboration study of the precursors of atherosclerosis in children. Protocol of the cardiovascular division of the World Health Organisation, 1975.

42. Willian, P., Robinson, D., and Beiley, A.: High-density lipoprotein and coronary risk factors in normal men. Lancet, $1: 72$ (1979).

43. The authors would like to thank Mrs Ch. Schopfer, nurse, and Mrs B. Kalix, F. Ruinard, B. Von Arx, technicians, for their great help during the study. We are most grateful to Professor O. Jeanneret, head of the Institut de Médecine Sociale et Préventive, Geneva, Dr P. Hazeghi, director of the Service de Santé de la Jeunesse, Geneva, Dr Th. Strasser, cardiovascular division of the World Health Organisation and Mr G. Fioretta, statistician, for their assistance in performing the study. We are indebted to Mrs A. Samai, Mrs B. Pfund for typing the manuscript and to Mr Rapart for the preparation of the diagrammes.

44. Requests for reprints should be addressed to: Dr. I. Oberhänsli, Clinique de Pédiatrie, 30 Blvd. de la Cluse, 1211 Geneva 4, Switzerland.

45. This research was supported grants $6.1300 .74,6.175-1.75$ and 3.843 .77 from the Swiss National Sciences Foundation.

46. Received for publication July 6,1981 .

47. Accepted for publication January $15,1982$.

Copyright (C) 1982 International Pediatric Research Foundation, Inc.

Printed in U.S.A. $0031-3998 / 82 / 1608-0665 \$ 02.00 / 0$

\section{PRESENTING THE BULLETIN OF THE INTERNATIONAL PEDIATRIC ASSOCIATION}

\section{THE BULLETIN OF THE INTERNATIONAL PEDIATRIC ASSOCIATION IS NOT JUST ANOTHER PEDIATRIC JOURNAL}

\section{READ THE BULLETIN OF THE IPA}

- Know more about what is happening in pediatrics in the world today.

- Enjoy papers in the "Special Contribution" section of the Bulletin by some of the most eminent pediatricians of our times.

- Gain an international perspective on matters of interest to you as a pediatrician.

- Keep abreast of IPA seminars, symposia and workshops on topics of the utmost importance to your profession.

- Learn when future international and regional pediatric meetings will be held and where to write for information.

Published quarterly in English, French and Spanish, the official languages of the International Pediatric Association, the Bulletin of the IPA provides a forum for the views of pediatricians from all over the world and an opportunity for you to know your colleagues in other countries.

\section{SUBSCRIBE TO THE IPA BULLETIN}

To receive more information concerning the Bulletin of the IPA please write to your national pediatric society or to the Managing Editor of the Bulletin at the address which follows:

Bulletin of the IPA

P.K. 2 Maltepe

Ankara, Turkey 